\title{
Investigating the Role of Pop Songs on Vocabulary Recall, Attitude and Retention of Iranian EFL Learners: The Case of Gender
}

\author{
Pouya Shakerian (Corresponding author) \\ Department of English, Faculty of Literature \& Foreign Languages, Kashan University \\ P.O. Box: 87317-51167, Isfahan, Iran \\ E-mail: crpouya@gmail.com \\ Omid Rezaei \\ Faculty of Foreign Languages, University of Isfahan \\ Hezar Jerib St., P.O. Box: 8174673441, Isfahan, Iran \\ E-mail: omidrezaei.rezaei99@gmail.com \\ Zeinab Toghyani Murnani \\ English Department, Faculty of Humanities, Najafabad Branch, Islamic Azad University \\ Najafabad, P.O. Box: 8514143131, Isfahan, Iran \\ E-mail: mina_toghyani@yahoo.com \\ Hamid Moeinmanesh \\ English Department, Faculty of Humanities, Najafabad Branch, Islamic Azad University \\ Najafabad, P.O. Box: 8514143131, Isfahan, Iran \\ E-mail: hamid_moeinmanesh@yahoo.com
}

Doi:10.7575/aiac.alls.v.7n.2p.121

URL: http://dx.doi.org/10.7575/aiac.alls.v.7n.2p.121
Received: 25/11/2015

Accepted: 21/01/2016

\begin{abstract}
Pop songs are, in fact, an ideal source for incidental vocabulary learning because teenagers often spend large amounts of their free time listening to music and in particular to pop songs. Employing an experimental approach, this study attempted to investigate the role of pop songs on vocabulary recall, attitude and retention of Iranian advanced adult EFL learners based on their gender. In so doing a language placement test (Quick Oxford Placement Test) was administered to 100 male and female language learners studying English at different language institutes in Esfahan, Iran. Ultimately, 60 advanced learners (30 males - 30 females) were selected by leaving out the students of other levels of proficiency and randomly divided into two relatively homogenous groups as musical and non-musical groups. While the students of musical group $(=30)$ were taught the new vocabulary in the syllabus through 60 different pop songs chosen by themselves through a questionnaire, the students of the non-musical group $(n=30)$ were taught new vocabulary without using the songs. The participants were examined based on an English vocabulary test developed by the researchers, which probed into the learners' vocabulary recall. A questionnaire was also used to investigate the attitude of the learners towards the instruction. A month later the vocabulary test was re-administered as a delayed retention test and obtained data were statistically analyzed. The results of t-tests demonstrated that the musical group outscored the nonmusical group on vocabulary recall and retention. The results also showed the male learners perform better than the females.
\end{abstract}

Keywords: incidental vocabulary, pop songs, vocabulary recall, attitude, retention

\section{Introduction}

To be enough proficient in English language, a learner should become master of the four principal skills of language (listening, speaking, reading, and writing) and language sub skills (grammar, vocabulary, pronunciation, and spelling). Among these sub skills, the vocabulary learning and teaching did not similarly receive its desirable attention in ESL/EFL classes until these recent decades. It was frequently considered that it would take account of itself and so did not get sufficient attention in ELT curriculums. As early as 1972, this lack of attention to L2 vocabulary learning in EFL contexts with the much-cited statement: "without grammar very little can be conveyed, without vocabulary, nothing can be conveyed" was indicated by Wilkins (p.111). As Biemiller (2006) notes there might be a significantly strong link between the vocabulary development and later development of literacy. The read-for-meaning ability requires some knowledge of vocabulary meanings. If the students' vocabulary is not enough rich, they cannot comprehend what they face in a text or what they listen to in a conversation. On the other hand, when someone masters 
the more vocabulary in English it would be easier for him to understand and communicate English itself. Flohr (2010, p. 2) stressed that students should learn vocabulary for otherwise they cannot express and express themselves in such a way that other native speakers of English can communicate with them. In EFL teaching context, Griva (2009) pointed out that learning of vocabulary has been regarded as basic and indispensible in language teaching area. Therefore, a large amount of vocabulary is now viewed as an inseparable part of communicative competence in second language and in parallel with this, and attempts to determine the most effective method of learning second language vocabulary have amounted. Since the 1980s, study and research into second language vocabulary learning has increased (Wang \& Kelly, 2013). With the emergence of humanistic approach, a large amount of attention was paid to the environment of language learning in classroom and increasing motivation and lowering the affective filter became an important aspect of language learning process.

Most of processes in learning are composed of knowledge which had been stored subconsciously; development of a multi-stimulant environment in the classroom increase learners' motivation and also contribute to their subconscious learning. In this case, the most useful learning environment should include music, drama and kinesthetic elements and should be rich enough in stimulants, which can address to various senses and reinforce positive emotions because these elements speed up subconscious learning (Cengiz, 2004).

Marin and Perry (1999) and Peretz (2006), stated that language and music have little and weak connection. The reason might be that music has pitch and rhythm, but speech doesn't, and grammar of the language may not be completely present in music, neither are semantic meanings. Furthermore, these researchers and others maintain that music can include more emotion and feeling than language (Patel 2008). But on the contrary, the literature also demonstrates that a rhythmic presentation might help memorization, especially when the presented verbal information is to some extent meaningful (Jones, 2010; Salcedo, 2002). Besides, a number of researches have been done on the effects of music and songs on different processes of brain (Zhang, Wang, \& Wu, 2011) during the process of learning and the results have demonstrated that melodies and songs can reinforce the processes of learning, and particularly language learning (Wallace, 1994; Peterson \& Thaut, 2006; Ozment \& Gurgen, 2010; Jones, 2010).

Maess et al. quoted in Setia (2012:271) point out that some neurologists have also found out that language and musical processing occur in the same hemisphere of the brain, and there might be parallels in how music and linguistic syntax are processed in human brain. As a result, employing English songs memorization which consists of a musical melody, regarded as a technique in language teaching, may help the students to accelerate their learning process, especially the learning of vocabulary.

Several other studies have demonstrated that teaching different skills and sub skills of a language employing songs might accelerate and facilitate the process of language learning (Sloboda, 1990; Fisher, 2001; Ransdell \& Gilroy, 2001; Ayotte, 2004; Neumam, 2004; Fischler, 2006; Schon, Magne \& Besson, 2008). For instance, Salcedo (2010) studied the effects of using song in the foreign language learning on text recall and involuntary rehearsal. His purpose was to explore whether English native speakers who are learning a foreign language can gain considerable advantage from integrating music into the syllabus. Students' text recall was examined after listening to the selected songs and text passages. The results revealed that in the condition of using songs recall was better than text passage. As well, Setia (2012) investigated the effects of exploiting songs in teaching English language to primary school curriculum. The results showed that the use of songs not only fosters the learners' comprehension, but also stimulates and reinforce the learners' confidence, when the activities are highly motivating and memorable.

Shen (2009) also maintained some criteria why the songs can be a liable and flawless tool in English language teaching. It can be because of the existence of different functions such as being a kaleidoscope of culture, having expressiveness, recitability, and relaxation, in songs. It can be supposed that English songs can provide many opportunities for vocabulary rehearsal. They usually consist of a theme or topic which can provide the useful context for vocabulary learning.

As another example, De Groot (2006) investigated the impacts of three stimuli and a musical background on pairedassociate vocabulary learning. The stimulus variables were the concreteness and frequency of the words of the native language (L1) and the typicality of the foreign language (FL) words. Sixty four word pairs (L1-FL) were taught six times, followed by a vocabulary recall test after the second, fourth, and sixth round of teaching. One week later a fourth recall test was performed. The typical FL words and the FL words which were paired with the frequent L1 words, and the FL words which were paired with the concrete L1 words were learned significantly better than the atypical FL words and the FL words which were paired with the infrequent and the abstract L1 words, in the same order. The results were interpreted regarding the differences between the memory representations of the L1 words, the differences in phonological coding process which was enabled by the FL words, and the individual learners' differences. The results revealed that more new words were learned when syllabus was integrated by songs than in the silent condition.

Collins (2013) also investigated the effects of music on the recall and retention of English language in elementary schools. Both of the music and interactive play were employed in this study to demonstrate that the combination of the two is a better strategy in language teaching than rote learning. This strategy was adopted for three days and one day was for testing. The study revealed that integrating music with interactive play in the English language vocabulary syllabus had significant effect neither on the vocabulary retention nor on the vocabulary recall, comparing the musical group with the non-musical one. 
Onur Köksal et al. (2013) also studied the effects of teaching vocabulary to $5^{\text {th }}$ graders using music on their vocabulary achievement, attitudes towards the English course and the retention of the learned words. The students in the musical group were taught the new vocabulary through songs composed by the researchers; on the contrary, the students of the control group learned the new vocabulary with the current English teaching programs. The study revealed that the teaching of English vocabulary using music enabled the learners to memorize the new vocabulary significantly better and the new vocabulary taught with music was stored for longer period of time.

Mohammad Alipour, et al. (2012) investigated the effects of songs on vocabulary recall and retention of upper-level EFL learners regarding their gender. The learners were examined based on a multiple-choice test to investigate their vocabulary learning through songs chosen by themselves, with different music genres such as pop, country, and rap. The results showed that the musical-mode group outperformed on both vocabulary recall and retention tests. Better performance of the male learners was also reported.

As the literature implicates, there is still a need for more investigation of the role of pop songs in vocabulary learning in order to find out whether vocabulary recall, retention, and attitude of Iranian EFL learners, studying English at different language institutes in Esfahan, Iran, would be affected by their favorite pop songs and their related lyrics. Consequently, this study seeks to provide answers to the following research questions:

(1) Is there any significant difference between musical-mode group and non-musical mode group in English vocabulary retention and recall?

(2) Is there any significant difference between male and female EFL learners in terms of the possible effects of using pop songs on EFL learners' vocabulary retention and recall?

(3) What is the learners' attitude towards using pop songs in teaching of English as a foreign language?

\section{Methodology}

\subsection{Participants}

Two different but advanced classes ( $\mathrm{n}=30+30$ ), aged from 20 to 32 , from the same institute were randomly assigned as the control and the experimental group, half of each group was male students and the other half was female. While the students in the experimental group were taught new words in the lesson through pop songs, the students in the control group were taught the same new words with the method in the current educational program.

\subsection{Instruments and materials}

\subsubsection{Tests}

An Oxford quick placement test (QPT) was administered to select two homogeneous groups based on the participants' language proficiency. The test consisted of 60 multiple-choice items on grammar and vocabulary. The time given to the test was 45 minutes. The scores could be between 0-60 and this conversion table was used to choose advanced learners.

Moreover, a vocabulary tests based on the lyrics of the used pop songs was developed by researchers. The British National Corpus was used to write the stems and the test was administered in the end (after 20 sessions). There were 30 items in each test which participants were required to answer in 22 minutes. The total score for the test was 30, each item has one point. The reliability of the test was met through the KR-21 formula and it was (0.77). One month later, this test was re-administrated to assess the retention of the words as well. An attitude questionnaire was developed to be completed by both groups to investigate the attitude of the learners towards learning vocabulary through songs.

\subsubsection{Survey}

A survey was administered to select the participants' most preferred singer or music bands in the form of a questionnaire. The questionnaire composed of three questions regarding the learners' musical interest. At first, the learners were required to write a list of their top ten favorite pop singers and groups, and in the second section, they were required to write a list of their top ten favorite pop songs. The last question was to find out how often the participants listened to their favorite pop music. Accordingly, some of the most preferred pop singers were Shakira, Rihanna, Beyoncé, Jennifer Lopez and etc. Therefore, the participants' favorite pop singers and music bands were selected based on their popularities among them.

\subsubsection{Songs}

As a result, the above-mentioned questionnaire provided the researchers the opportunity to choose the participants' most favorite pop singers and music bands. As a result, 60 different pop songs were chosen by the learners through the questionnaire and three songs were taught in each session. The researchers tried to consider the participants' social and religious values and norms as far as the contents of the chosen songs were concerned. For example, some of the chosen songs had a lot of taboo words, like "f" words which were not appropriate for the classes, so the researchers had to discard such songs.

Furthermore, the lyrics had to be relatively compatible with the learners' English knowledge; so the chosen songs, for example, which had a lot of slangs or idioms, were discarded too.

\subsection{Procedure}

In every session, a listening activity was at the beginning for each song. The song was played while a copy of the lyric of the song with some deleted new words was distributed to the participants to fill in the deleted parts. The song was replayed and the participants were asked to give their answers. In the end, the words were also written on the board for 
those who might have missed some of the answers. Some writing activities were added in which the participants had to use the new words to do the language activities such as giving definitions for the words and writing synonyms, making some sentences and writing a summary of the song lyrics using those new words. After practicing the new vocabulary items, there was a discussion about the topic or the story of the song every session. The whole activities and exercises for each song took for about 25 minutes. Three songs were used and practiced every session. The length of each song was about four to five minutes and the class time was about one and a half hours.

In the control group class, no song was played but the lyric of each song was distributed to the participants. The teacher read the lyrics part by part while the participants were writing the answers of the deleted parts. The participants tried to guess the meaning of the new words based on the context. Then, after practicing and reviewing the new words through writing definitions and synonyms, there was a discussion about the topic or story of the song. At the end of each five sessions, the developed vocabulary test was administered to evaluate the participants ' vocabulary recall. The same test was re-administered after each tenth session to investigate the participants' vocabulary retention. Altogether, there were 20 sessions of instruction for both of the groups which lasted for almost two months.

\section{Results}

Finally after the related statistical analyses conducted in the end of the study, the following results were obtained:

In this ANCOVA test which is tabulated below, the recall test scores are used as the dependent variable, the pretest scores as the covariate, and sex and the two groups as the independent variables.

Table 1. Tests of Between-Subjects Effects

\begin{tabular}{|c|c|c|c|c|c|}
\hline Source & $\begin{array}{lr}\text { Type } & \text { III } \\
\text { Sum } & \text { of } \\
\text { Squares } & \end{array}$ & $\mathrm{df}$ & Mean Square & $\mathrm{F}$ & Sig. \\
\hline Corrected Model & $337.994^{\mathrm{a}}$ & 4 & 84.499 & 40.980 & .000 \\
\hline Intercept & 204.985 & 1 & 204.985 & 99.415 & .000 \\
\hline Pretest & .061 & 1 & .061 & .030 & .864 \\
\hline Group & 296.509 & 1 & 296.509 & 143.802 & .000 \\
\hline Sex & 35.023 & 1 & 35.023 & 16.985 & .000 \\
\hline Group * Sex & .256 & 1 & .256 & .124 & .726 \\
\hline Error & 113.406 & 55 & 2.062 & & \\
\hline Total & 35300.000 & 60 & & & \\
\hline Corrected Total & 451.400 & 59 & & & \\
\hline
\end{tabular}

Regarding table 1, we can find no interactional effect between sex and the groups, since the last row of the table shows sig $=0.726$. It means that using these variables at the same time does not affect the main test results and they can be separately investigated.

For the covariate (the pretest) $\mathrm{sig}=0.864$ is more than 0.05 which means that the pretest had no effect on the obtained results (after the musical instruction), so the results are reliable enough.

The value of the significance level for the groups equals $0.000<0.05$ which means that the musical-mode group's performance and that of the control group are significantly different. In other words, the musical-mode group's performance was positively affected by the musical instruction, since the mean score of this group was 4.47 more. Finally the degree of significance for the sex variable was sig $=0.000$ which shows that men outperformed in the test and the musical instruction improved their performance more.

Retention of the instruction:

In this ANCOVA test which is tabulated below, the retention test scores as the dependent variable; the recall test scores and the pretest as the covariate; and sex and groups as the independent variables have been examined. 


\begin{tabular}{llllll}
\hline Table 2. Tests of Between-Subjects Effects & & & & Mean Square & F \\
\hline Source & $\begin{array}{l}\text { Type III Sum } \\
\text { of Squares }\end{array}$ & df & & & \\
\hline Corrected Model & $277.841^{\mathrm{a}}$ & 5 & 55.568 & 42.178 & .000 \\
Intercept & 6.299 & 1 & 6.299 & 4.781 & .033 \\
Recall & 47.883 & 1 & 47.883 & 36.345 & .000 \\
Pretest & .683 & 1 & .683 & .519 & .475 \\
Sex & 2.353 & 1 & 2.353 & 1.786 & .187 \\
Group & 1.723 & 1 & 1.723 & 1.308 & .258 \\
Sex * Group & .625 & 1 & .625 & .474 & .494 \\
Error & 71.143 & 54 & 1.317 & & \\
Total & 34861.000 & 60 & & & \\
Corrected Total & 348.983 & 59 & & & \\
\hline
\end{tabular}

Regarding table 2, there is no interactional effect between the group and sex variable because the sig=0.494, which is also shown in the last row of the table. It means that the co-existence of these two variables had no effect on the main test results and they can be separately examined.

The value of the significance level for the pretest variable was more than $0.05(\mathrm{sig}=.475)$ showing that this test had no effect on the results so the results are more reliable. In the recall test the value of the significance level was sig $=0.000<0.05$. So it means that this test had a significant effect on the results, consequently this value of level significance indicates that there is a relationship between this test and the recall test and the retention of the musical instruction is obvious as expected.

The significance level value of the group variable equals $0.258>0.05$, so there was no significant difference between the two groups' performance in the retention test. In another words it can be said that forgetfulness plays no decisive role here and the obtained mean scores of the musical-mode group were still more than the control group (25.76>22.2). Thus the knowledge of musical instruction has not been forgotten. Finally the value of the significance level for the sex variable was 0.187 , indicating that the levels of men and women's performance were not significantly different when the retention of the instruction was under examination.

To manifest the attitude of both musical and non-musical groups towards the instruction of vocabulary in their classes the results of the questionnaire were put into chi square.

Table 3. Group * variable Cross tabulation

\begin{tabular}{lcccc}
\hline & $\begin{array}{c}\text { Negative } \\
\text { Attitude }\end{array}$ & Positive Attitude & Neutral Attitude & Total \\
\hline $\begin{array}{l}\text { Non-musical group } \\
\text { Musical group }\end{array}$ & 270 & 120 & 585 & 975 \\
Total & 210 & 75 & 810 & 1095 \\
\hline
\end{tabular}

Regarding table 3, non-musical group showed more negative attitude towards vocabulary instruction in comparison to musical group. It can also be seen that musical group manifested more positive attitude towards vocabulary instruction comparing to non-musical group.

\section{Discussion and conclusion}

This study attempted to investigate the role of pop songs on vocabulary achievement, attitude and retention of Iranian advanced adult language learners based on their gender. The results indicate that teaching new vocabulary through music has significantly increased achievement in English vocabulary learning, positive attitudes toward the musical instruction and the retention of new vocabulary of the students in the musical-mode (experimental) group compared to the nonmusical-mode (control) group. Interestingly, musical-mode group students obtained higher scores whether immediately after the instruction or after the interval. In terms of attitudes towards English learning, the musical-mode group had a more positive attitude towards English learning and showed greater degree confidence, too.

This musical instruction had several benefits to the class. First, the atmosphere of the class was almost free of any stress and anxiety during the musical instruction and the "affective filter" was low. The students were more focused and attentive to the lyrics to find and learn the new vocabulary and their feedback showed that the musical instruction was of great interest. Some learners maintained that they realized they could acquire new words (Zhang, Wu, Wei \& Wang, 
2011 ) through the songs too and not just through books and movies and they suggested to keep on using pop songs even after the experiment. The students realized that this method of instruction for vocabulary learning had new dimensions (Zhang \& Wu, 2011). Generally learning the new words became more funny and effective. This effectiveness could be achieved because the songs help the learners to have more pleasure during the learning process and singing the songs makes students easily to memorize and remember the new words and doing the same actions of the song make students understand what the lyric or new word meaning is without asking or looking them up in a dictionary. Second, acquiring and memorizing the new words were not a boring and difficult activity, since their chosen pop songs were employed in the instruction. Third, the students became more familiar with a large number of new social and cultural matters through the used songs (Gorjian, Alipour \& Saffarian, 2012) that made the instruction more fulfilling and interesting for them. Finally, the students' cooperation in the class was more noticeable and the learners were more motivated in learning vocabulary items using songs (Gorjian, Pazhakh \& Naghizadeh, 2012). Therefore, based on these findings, an EFL class which is intensively based on songs appears to be highly effective in English teaching, in terms of achievement, retention, and attitudes towards English learning.

Since employing songs is a generally demanding task to the English teachers, only few academic empirical studies have so far studied the actual effectiveness of songs or music on language learning. The result of this study is in parallel with some of the studies on the use of music in language teaching (Šišková, 2008; Schuster and Mouzon, 1982, and Gfeller, 1983). Moreover, Medina (2000) maintains that music and its subcomponent, rhythm, in the psychological research have both been demonstrated to boost the rote memorization process.

In a study done in Hong Kong, it is reported that vocabulary memorization levels of the learners who are interested in music or play a musical instrument at their early ages is higher up to $16 \%$ compared to other learners (Cengiz, 2004). In another study by this researcher in which brain-based learning activities involved using of music were employed, it was revealed that music had positive effects on students' achievement levels. In another study by Baş (2010), based on brain-based learning in English lessons and involving learning by listening to some pieces of music and creating songs, it was reported that the activities done in the musical-mode group had some positive effects on the learners' achievement and attitudes towards this kind of instruction.

The effects of songs on vocabulary recall and retention were also investigated by Mohammad Alipour, et al. (2012) employing upper-level EFL learners considering the possible effects of their gender. Their results showed the outperformance of the musical-mode group on both vocabulary recall and retention tests and better performance of the male. In a similar study done by Onur Köksal et al. (2013), the possible effects of teaching vocabulary to $5^{\text {th }}$ graders, employing songs on their vocabulary achievement, retention and attitudes towards the course, were investigated. Their study demonstrated some positive effects of songs on the teaching of English vocabulary. The songs helped the learners of the musical-mode group memorize the new vocabulary significantly better, their vocabulary retention was enhanced and their attitudes towards the instruction were to a large extent positive.

Using music in language learning can enable learners to open all of their memory channels and thus the more channels are used in learning, the learning will be increased more. Information which has been encoded in different memory systems is recalled more readily and more easily as it can be called back from any possible memory system. It can also be deduced from this fact that students who can memorize new words in different components of memory by virtue of music can recall them more easily.

Therefore, it was inferred that teaching of English vocabulary to adult learners through music enabled them to enhance the retention of new vocabulary in their minds more meaningfully. This method of musical instruction applied in the musical-mode group is more effective in comparison with the one applied in the nonmusical-mode group and that new vocabulary which has been taught using music is learnt much better and stored for a longer period of time. Employing another area of intelligence like musical intelligence to develop an area of intelligence will have some positive effects, as it is also emphasized in the theory of Multiple Intelligence. Eventually, it is discussed that the incorporation of music as a means of supplementary element in teaching of vocabulary in different programs applied by institutes will be of great contribution to the ease of learning and will provide longer retention. Understanding its high effectiveness, EFL/ESL teachers are highly recommended to exploit different songs to foster learners' vocabulary growth and development.

Finally, this study employed pop songs for Iranian adult EFL learners; future researches might investigate the role of music on learners of other countries or cultures. It would also be interesting to study music effectiveness on other language skills or sub-skills.

\section{References}

Alipour, M., Gorjian, B., Zafari, I. (2012). The effects of songs on EFL learners' vocabulary recall and retention: The case of gender. Advances in Digital Multimedia (ADMM), 1, 140-143.

Ayotte, S. B. (2004). The acquisition of verb forms through song. Dissertation Abstracts International, A: The Humanities and Social Sciences, 65(9), 3356-A.

Baş, G. (2010). Beyin Temelli Oğrenme Yonteminin İngilizce Dersinde Oğrencilerin Erisilerine ve Derse Yonelik Tutumlarına Etkisi. Illköğretim Online, 9(2), 488-507. 
Biemiller, A. (2006). Vocabulary development and instruction: A prerequisite for school learning. In D. Dickinson \& S. Neuman (Ed.), Handbook of early literacy research (Vol. 2, pp. 41-51). New York: Guilford Press.

Cengiz, Y. (2004). Yabancı Dilde Sozcuk Öğretimine Muzik Kullanımının Etkilerinin Beyin Temelli Ŏgrenme Kuramı Isı̆̆ında Arastırılması (Unpublished master thesis). Ankara University, Ankara, Turkey.

Collins, H. M. (2013). The effects of music on foreign language retention in elementary schools, Unpublished MA Thesis. University of Southern Mississippi, the U.S.

de Groot, A. (2006). Effects of stimulus characteristics and background music on foreign language vocabularylearning and forgetting. . Language Learning, 56, 463-506.

Fischler, J. (2006). The rap on stress: Instruction of word and sentence. Unpublished Master thesis. Hamilton University, Minnesota.

Fisher, D. (2001). Early language learning with and without music . Reading Horizons, 42(1), 39-49.

Flohr, S. (2010). Retrieved May 20, 2010, from Presenting and teaching vocabulary in the EFL classroom: http://www.grin.com

Gfeller, K. E. (1983). Musical mnemonics as an aid to retention with normal and learning disabled students. Journal of Music Therapy, 20, 179-189.

Gorjian, B., Alipour, M., \& Saffarian, R. (2012). The effect of multisensory techniques on reading comprehension among pre-intermediate EFL learners: The case of gender. Advances in Asian Social Science, 1(2), 192-196.

Gorjian, B., Pazhakh, A. R., \& Naghizadeh, M. (2012). Comparative study of conjunctive adverbials (CAs) in native researchers' (NRs) and non-native researchers' (NNRs) experimental articles. Advances in Asian Social Science, 1(2), 224-247.

Gorjian, B., Pazhakh, A. R., \& Parang, K. (2012). An investigation on the effect of critical thinking (CT) instructions on Iranian EFL learners' descriptive writing: A case of gender study. Advances in Asian Social, 1(1), 114-118.

Griva, E. (2009). Retrieved April 10, 2012, from Young learners' vocabulary strategies employment in a foreign language: http://ressources-cla.univ-fcomte.fr/gerflint/SE_europeen2/griva.pdf

Jones, A. (2010). Music and cognitive process student perceptions. Polyglossia, 19(2010), 143-150.

Köksal, O. (2012). The effect of mnemonic devices on achievement, attitude, vocabulary learning and retention on the fifth year primary school English lessons (Unpublished doctoral dissertation). Necmettin Erbakan University, Konya, Turkey.

Köksal, O., \& Yağışan, N., \& Çekiç, A. (2013). The effects of music on achievement, attitude and retention in primary school English lessons. Procedia - Social and Behavioral Sciences, 93, 1897-1900.

Marin, O. S. M., \& Perry, D. W. (1999). Neurological aspects of music perception and performance. In D. Deutsch (Ed.). In The Psychology of Music (2nd ed., pp. 653-724). San Diego: Academic Press.

Medina, S. L. (1990). The effects of music upon second language vocabulary acquisition. Paper presented at the TESOL conference, San Francisco, CA, the U.S.

Neumann, S. B. (2004). Hear, Hear. Scholastic Parent and Child, 11(4), 22-23.

Ozmentes, S., \& Gurgen, E. T. (2010). Pre-school and elementary school pre-service teachers' learning outcomes for music. Procedia Socal and Behavioral Science, 9, 444-449.

Palmer, C., and Kelly, M. (1992). Linguistic prosody and musical meter in song. Journal of Memory and Language, 31, 525-541.

Patel, A. D. (2008). Music, language, and the brain. New York: Oxford University Press.

Peretz, I. (2006). The nature of music from a biological perspective. Cognition, 100, 1-32.

Peterson, D. A. (2006). Music increases frontal EEG coherence during verbal learning. Cognition, 19(4), $133-149$.

Ransdell, S. E., \& Gilroy, L. (2001). The effects of background music on word processing writing. Computers in Human Behavior, 17(2001), 141-148.

Salcedo, C. S. (2002). The effects of songs in the foreign language classroom on text recall and involuntary mental rehearsal. Dissertation Abstracts International, A: The Humanities and Social Sciences, 63(11).

Salcedo, C. S. (2010). The effects of songs in the foreign language classroom on text recall, delayed text recall and involuntary mental rehearsal. Journal of College Teaching \& Learning, 6, 19-30.

Schon, D., \& Magne, C., \& Besson, M. (2004). The music of speech: Music training facilitates pitch processing in both, music and language. Psychology, 41(2004), 341-349.

Schuster, D., \& Mouzon, D. (1982). Music and vocabulary learning. Journal of the Society for Accelerative Learning and Teaching, 7(1), 82-106.

Setia, R. (2012). English song as a means of aiding students' proficiency development. Retrieved January 9, 2013, from (online), (www.ccsenet.org/ass) 
Shen, R. (2009). Using English Song: an Enjoyable and Effective Approach to ELT. Retrieved February 12, 2012, from (Online), (http://ccsenet.org)

Šišková, D. (2008). Teaching vocabulary through music. Diploma Thesis. Masaryk University, Brno, Czech Republic.

Sloboda, J. (1985). The musical mind: The cognitive psychology of music. New York: Oxford Science.

Wallace, W. T. (1994). Memory of music: effect of melody on recall of text. Journal of Experimental Psychology: [19] Learning, Memory, and Cognition, 26(6), 1471-1485.

Wang, D. \& Kelly, P. (2013). Making vocabulary memorization strategies more effective and enjoyable for first year Chinese university students. The English Teacher, XLII(2), 74-88.

Zhang, Y \& Wu, L. (2011). Crop classification by forward neural network with adaptive chaotic particle swarm optimization. Sensors, 11(5), 4721-4743.

Zhang, Y, Wu, L, Wei, G, \& Wang, S. (2011). A novel algorithm for all pairs shortest path problem based on matrix multiplication and pulse coupled neural network. Digital Signal Processing, 21(4), 517-521. 